\title{
THE DEGREE OF DEFENDANT'S FAULT AS AFFECTING THE ADMINISTRATION OF THE LAW OF EXCESSIVE COMPENSATORY DAMAGES *
}

\section{Ralpe S. Bauer $\dagger$}

Is there a notable tendency in courts, in the administration of the rule that compensatory damages must not be excessive, to allow larger compensatory damages against the defendant who has done a wrong either wilfully or recklessly than against one who has acted with mere negligence? Does the likelihood that a very large verdict will be set aside as excessive vary in inverse ratio to the degree of moral fault of the defendant? Is a court usually ready to sustain a verdict for very large compensatory damages against a wilful or reckless wrongdoer and somewhat less ready to sustain a similar verdict against a merely negligent wrongdoer? These questions we shall try to answer by a study of cases.

It would, of course, be unreasonable to argue that compensatory damages, where they are absolutely certain in amount and completely incapable of any plausible stretching by the jury, could ever be lawfully stretched into greater compensatory damages by reason of even the greatest fault. For instance, if the defendant has destroyed the plaintiff's case of eggs, according to all the evidence worth exactly $\$ 9.02$, no kind of legerdemain by the jury, winked at by a complacent trial judge, can enlarge the compensatory damages to an amount greater than $\$ 9.02$ for the direct damage done by the destruction of plaintiff's property. Theoretically, perhaps this is always true as to compensatory damages.

But, actually, even compensatory damages have often been at large, practically in the discretion of the jury except for a very slight control by the court, where the amount of actual damage is difficult to ascertain. Compensatory damages in personal injury cases usually include damages for a number of items that are completely impossible to evaluate at any certain figure. Physical pain and mental suffering are not capable of any definitely

* This is a sequel, so to speak, to the article, The Dcgree of Moral Fanlt as Affecting Defendant's Liability (I933) 8I U. of PA. L. REv. 586, which treated fault as affecting liability in general, with special attention to the principles of certainty and causation. The present article leaves out of consideration the principle of exemplary damages, just as far as this is possible, that is, everything named exemplary damages is omitted. Of course it is fully realized that, in actuality, there is not always a complete severing of the compensatory and the exemplary. Exactly as in the days before exemplary damages were given judicial recognition in name, courts and juries today frequently allow exemplary damages under the name of compensatory damages, and it is believed that this is one thing indicated by a number of the cases cited.

† A.B., Ig04, University of Illinois; A.M., I906, James Millikin University; J.D., I909, University of Chicago; Professor of Law, De Paul University Law School; author of works on damages and business law, and contributor to numerous legal periodicals. 
accurate appraisals. Damage suffered through loss of earning power, though not so indefinite in amount as physical pain and mental suffering, is a matter on which greatly varying conclusions might be reached without appearance of any probable error, and therefore a large stretching-upward of compensatory damages for earning power, if not so large as to seem rather striking, may easily pass without the court's notice. Likewise, in cases of interference with the business of plaintiff by defendant, whether it be a malicious interference in violation of rules of common law, or a violation of anti-trust statutes, or infringement of patents or copyrights, there may be instances presented in which the damage done is rather manifestly large but impossible to compute with accuracy, and this fact, as we shall see, has tended toward the judicial approval of very large verdicts for wilful injury to business, whether the action is brought under the common law or under statutes, and whether large damages are strictly proved or not.

Usually, the question of moral fault is not dragged into the open by the court in disposing of questions of merely compensatory damages; and yet, in some instances, there has been a frank discussion of defendant's fault. One court said: "If the damages seem large, they are not, so far as we are permitted to judge, out of proportion to the fault." 1

Even in contract, it seems that degree of fault figures in the administration of the rules of certainty and causation. ${ }^{2}$ It appears that the degree of fault of the contract-breaker is likely to affect the settlement of the question of allowance of large compensatory damages. ${ }^{3}$

${ }^{1}$ Severens, J., in Kentucky Distilleries \& Warehouse Co. v. Lillard, 160 Fed. 34, 40 (C. C. A. 6th, Ig08).

"While defendant is without moral fault with respect to this delay, plaintiff is equally innocent; and it need not be said that, as between the parties before us, contract rights and liabilities must govern." Knappen, J., in South Memphis Land Co. v. McLean Hardwood Lumber Co., 210 Fed. 257,262 (C. C. A. 6th, I9I4).

${ }^{3}$ On the kind of judicial treatment accorded wilful breakers of contracts in the administration of the rule of certainty of proof, see article referred to sulpra note *, at $592 \mathrm{n}$. I7.

${ }^{3}$ An action was brought on the contract for the sale of distillery slops for feeding. The contract provided that plaintiff, a distillery company, would sell and deliver, and that defendants would purchase, receive, and accept the slops at a feeding lot leased by defendants to plaintiff, where defendants should have the privilege of using the necessary troughs and tubs which plaintiff was to place and connect in a manner suitable for feeding. Plaintiff broke its contract by failing to furnish a sufficient number of troughs and tubs, in consequence of which 67 of defendants' cattle died of starvation, and 1,340 failed to fatten to the extent that they might reasonably have been expected to fatten. Judgment was affirmed on a verdict for defendants in the sum of $\$ 7,000$ and costs. The court said: "From the testimony shown in the record, we think the jury might have given the defendants a larger verdict than they did. And the damages were not remote. They were the natural and probable result of conditions for which the plaintiff was responsible. If the damages seem large, they are not, so far as we are permitted to judge, out of proportion to the fault." Kentucky Distilleries \& Warehouse Co. v. Lillard, stepra note I, at 40. If the court had regarded the moral fault of the plaintiff as being not very serious, would the court thus lightly have held the plaintiff liable for such a consequence as the death by starvation of 67 of defendants' cattle, an unusual consequence and more than possibly one shown by the record to be avoidable? The court seems to be impressed with the greatness of the fault of plaintiff. 
In cases of wilful tort, there is a considerable number of instances in which verdicts for questionably large damages have been allowed to stand, without any mention of exemplary damages. In such cases, it would seem that the courts have affirmed judgments, on large verdicts, with somewhat less hesitancy than would have existed if the defendant had been guilty of mere negligence. Cases of assault and battery and of false imprisonment afford excellent examples of this tendency. ${ }^{4}$ A distinction between the wilful

Defendants made a rather vague promise to plaintiff, in purchasing land of plaintiff, that they would build thereon "a good steam saw-mill". Despite the uncertainty as to what kind of mill was to be built, the court affirmed judgment for plaintiff in the sum of $\$ 500$. Not all of the facts are made clear by the report, but it seems to be a case of flagrant breach of contract. Fraley v. Bentley, I Dak. 25, 46 N. W. 506 (I874).

Cochran v. People's Ry., I31 Mo. 607, 33 S. W. 177 (I895), is a case in which defendant was allowed to recover, on a counterclaim, only \$Ioo, the amount allowed by the verdict, although all witnesses estimated the damage to woodwork, due to plaintiff's failure to roof the building for defendant promptly, at $\$ 320$. It seems that plaintiff had been rather unfortunate in attempts to build for defendant, bad weather hindering him. The trial court erroneously admitted evidence of such bad weather, which was irrelevant, as the terms of the contract made no provision against bad weather. The court was probably influenced, in allowing the verdict to stand, by the fact that it did not regard plaintiff as being morally at fault in the breach of his contract.

- Defendants took plaintiff to a field, stripped and severely beat him, and forced him to leave home. Held, that a verdict for $\$ 4,000$ is not excessive. The court said: "Finally, it is contended by the appellants that the damages assessed by the jury are excessive. We do not agree with this contention. The assault and battery charged and proven at the trial was of an aggravated character; and the jury, who heard the evidence, and had the parties and witnesses before it, were the best judges of the amount necessary to compensate the appellee for the injuries he had received at the hands of the appellants." As far as we can judge from the report of the case, it seems unlikely that $\$ 4,000$ compensatory damages would have been allowed for similar injuries in the same year in a negligence case. Morgan v. Kendall, I24 Ind. 454, 463, 24 N. E. I43, I46 (I890).

In Duer v. Gagnon, I29 Minn. 517,152 N. W. 880 (xgI5), plaintiff sued defendant for assault and battery. Plaintiff was confined to a hospital for about I4 weeks, suffercd much pain, was put to considerable expense, and was on crutches at the time of the trial, from the facture of the larger bone in his right leg. Judgment for plaintiff for \$I,g00 was affirmed. The court said, at $5 \mathrm{Ig}, \mathrm{I} 52 \mathrm{~N}$. W. at 88I : "Under the circumstances, we cannot say that the damages are excessive or that the jury was influenced by prejudice or passion." The court seems to stress "the circumstances", implying that they affect the question of excessive damages, without mentioning exemplary damages.

Cummins v. Crawford, 88 Ill. 312 (1878), was a case of trespass for shooting and wounding of plaintiff by defendant. Judgment for plaintiff, in the sum of \$I,950, was affirmed. The shooting was with a double-barrelled shot-gun. One barrel was loaded with powder and leaden ball, and the other with powder and small "turkey shot" or "small buck shot". The one first discharged was the rifle ball, which took effect in plaintiff's left breast, passing through a part of the lungs and coming out near the shoulder blade, and the shot from the other barrel took effect in his leg. The wounds were such as might disable hin for life. The issue of exemplary damages does not appear to have been raised at all; but the court said, at 319: "The injuries inflicted upon plaintiff are serious-such as may disable him for life; and the damages found are not excessive. Besides, the assault was wanton, and the circumstances proven would warrant the jury in imposing upon defendant a measure of punishment as exemplary damages. The law distinguishes between injuries inflicted under influences of sudden passion and such as are planned and executed with deliberation. In this case, defendant was moved by no sudden impulse, but waited calmly until his adversary advanced near enough, and then shot him, with a matured purpose to kill him. Such deliberation is seldom witnessed th the commission of acts of violence."

In Royer v. Belcher, $100 \mathrm{~W}$. Va. 694, I3I S. E. 556 (I926), judgment on the verdict of $\$ 250$ in favor of plaintiff was affirmed. Plaintiff had to expend about $\$ 50$ as a result of the battery by defendant. The court said, at 697 , I3I S. E. at 557 : "The actual damages to which he was entitled included not only his monetary outlay, but damages for his physical injuries, pain, and humiliation. Would a less sum than \$250 compensate him for his actual damages? Unless we can so determine, we cannot hold that any punitive damages are included in the verdict." 
and the mistaken taking of minerals from land of the plaintiff is openly and directly recognized and well known to the legal profession, a much more severe measure of damages prevailing against the wilful wrongdoer. ${ }^{5}$

The examination of a considerable number of cases of personal injuries, nearly all decided in recent years, each involving a verdict of $\$ 20,000$ or more, selected in a uniform manner and without any intention to influence the result of this investigation, indicates that, under similar or at least fairly comparable circumstances, the chance of getting judgment affirmed on a verdict of $\$ 20,000$ or more, or at least keeping it from being reduced below $\$ 20,000$, is roughly twice as great in cases of reckless misconduct as it is in cases of mere negligence. A similar examination indicates that the chance of getting a verdict of $\$ 20,000$ or more reduced to a point under $\$ 20,000$ is roughly twice as great in negligence cases as it is in those of reckless misconduct.

Of course we must not ignore the fact that the actual amount of damage suffered in some of these cases governs the case, without the necessity of giving any attention to degree of fault. Theoretically, this would regularly

One.case in which it might seem that the idea of approving very large verdicts for compensatory damages in cases based upon assault and battery is carried too far, is the well known case of Mohr v. Williams, 95 Minn. 26r, I04 N. W. 12 (I905). Defendant, a surgeon, had placed plaintiff under an anaesthetic, for the purpose of operating upon her left ear, in accordance with plaintiff's consent. A close examination revealed that an operation on the left ear was unnecessary. Defendant examined the right ear and found that there existed in it conditions that presented serious dangers to plaintiff's health in the future. Therefore defendant operated on the right ear. It was admitted that the operation was skillfully performed and of a beneficial nature. Yet the trial court gave judgment on a verdict for $\mathrm{SI}_{1}, 000$, which was affirmed on appeal. Evidently the court was willing to allow a much larger verdict to stand than would have been allowed in a negligence case on any facts closely resembling those in this case. This seems a perversion of the general tendency to allow greater compensatory damages where the fault is great, as the mere fact that the defendant's act happens to constitute technically an assault and battery should not becloud the fact that he is guilty of very little moral fault, if any. Certainly a great many persons today, and many of the courts, would gladly approve what the defendant did in this instance as a strictly moral, as well as legal, act of the surgeon under the circunstances, the implication of consent existing in at least some of the states.

Cordell v. Standard Oil Co., I3I Kan. 22I, 289 Pac. 472 (1930), was a case in which defendant's agent at a gasoline filling-station wrongfully detained plaintiff, a woman, while defendant's agent informed police that she was a felon or a part of the forerunner of a robbery. Plaintiff had a verdict of $\$ 500$, on which the trial court gave judgment, which was affirmed. No question of exemplary damages was involved. The tort here is one classified by the law as wilful, as contrasted with negligent, although the motive may have been honest. The judgment here was for a large amount, when it is compared with the amount of damage evidently done.

${ }^{\circ} A$, by mistake, takes minerals from $B$ 's land. The measure of damages in either trover or trespass is ordinarily held to be the value of the minerals in place in the land. "Where the defendant's conduct, measured by the standard of ordinary morality and care, which is the standard of the law, is not chargeable with fraud, violence, or wilful negligence or wrong, the value of the property taken and converted is the measure of just compensation. If raw material has, after appropriations and without such wrong, been changed by manufacture into a new species of property, as grain into whiskey, grapes into wine, furs into hats, hides into leather, or trees into lumber, the law either refuses the action of trover for the new article, or limits the recovery to the value of the original article. . . . Where there is no wrongful purpose or wrongful negligence in the defendant, compensation for the real injury done is the purpose of all remedies; and so long as we bear this in mind, we shall have but little difficulty in managing the form of action so as to secure a fair result." Forsyth v. Wells, 4I Pa. 29I, 296 (I86r). 
be so, and, actually, the affirmance of judgment on a large verdict is often completely explicable on the ground of large damage actually suffered, just as the reversal of judgment on a large verdict may often be explained by the smallness of the actual damage. In some of the reported cases, the amount of damage is hard to ascertain, by reason of the meagerness of the facts stated, and, in some instances, the character and degree of the fault of the defendant are, for the same reason, difficult or impossible to learn. This makes a satisfactory examination of some of the cases difficult and fated to produce only somewhat obscure results, although the study of some other cases affords a sufficient yield of good data to make for results genuinely indicative of judicial tendencies.

Certain very dangerous railroading practices, probably only rarely indulged in, have more or less clearly amounted to reckless misconduct, and some interesting cases, terminating in the affirmance of judgments on very large verdicts, have resulted. Running a train on a wrong track may constitute reckless misconduct. A very clear case of reckless misconduct is Chicago \& Eastern Illinois $R$. R. v. Holland, ${ }^{\circ}$ in which defendant's employees, in violation of the express rules of the Rock Island Railroad, on which plaintiff was a conductor, placed defendant's train on the Rock Island track, wilfully taking the chance of a collision, upon the occurrence of which plaintiff was severely and permanently injured. A verdict for $\$ 25,000$ was held not excessive.

Almost as reckless is the case in which a railroad company has wilfully taken the chances naturally resulting from leaving a switch open. Such a case is Andrezes $v$. Wilding, ${ }^{7}$ in which plaintiff, an employee on defendant's railroad, was badly injured in a wreck caused by an open switch without lock or light. A verdict for $\$ 22,000$ was held not excessive.

In Spencer v. Chicago \& Northwestern $R y .{ }^{8}$ the court upheld a verdict for $\$ 22,500$, to which sum it had been reduced by the trial court from $\$ 30,000$. Plaintiff, forty-two years old, a brakeman-collector of defendant, was injured by reason of a switch left open. He had practically lost the use of a leg. Probably the leaving of the switch open would be considered reckless misconduct.

Running a railroad train, on a dark night, without a headlight, may well be treated as reckless misconduct. In Savage $v$. Chicago, etc. $R y .{ }^{\circ}{ }^{3}$ plaintiff was struck by defendant's locomotive, which bore no headlight,

'I8 Ill. App. 418 (1886), aff'd, I22 Ill. 46I, I3 N. E. I45 (I887). In Hall v. Chicago, etc. R. R., 46 Minn. 439,49 N. W. 239 (I89I), the reckless misconduct is obvious. Plaintiff, defendant's engineer, on a passenger train, was badly injured by a collision of his train with freight cars which a switching crew ran on the main track, in violation of rules of the company. A verdict for $\$ 25,000$ was held not excessive.

${ }^{7}$ I93 S. W. 192 (Tex. Civ. App. 1917).

${ }^{8} 249$ IIl. App. 463 (I928).

${ }^{\circ} 328$ Mo. 44 , 40 S. W. (2d) 628 (193I). 
although the night was very dark. Plaintiff was forty-six years old, earning between \$I 54 and \$I9I per month. He lost two fingers, and his right hand and arm were rendered practically useless, his skull was fractured, causing pressure on the brain, and he suffered dizzy spells, nervousness and loss of control ; in addition, there was evidence that he would grow worse. A verdict for $\$ 20,000$ was held not excessive.

Under some conditions, undoubtedly it constitutes reckless misconduct for a railroad train to approach a grade crossing without any warning. A case involving such conduct is Ramey $v$. Missouri Pacific $R . R .{ }^{10}$ in which plaintiff suffered cuts and bruises, dislocated and broken collar bone, broken nose, fractured skull, ruptured blood vessel in the brain, unconsciousness for ten days, sojourn in hospital for twenty-five days, medical expenses of $\$ 675$, and partial and progressive paralysis. A verdict for $\$ 25,000$ was held not excessive. Defendant's train, proceeding at forty or fifty miles an hour, through a village, across a street from which plaintiff could not see it until within five or ten feet of the track, struck plaintiff, who was driving an automobile. The train neither rang a bell nor blew a whistle within a quartermile of the crossing. The facts seem to indicate a wilful taking of a chancereckless misconduct.

It seems a fairly clear case of reckless misconduct to carry on a construction train a bar of iron projecting five or six feet in a slanting direction in such a manner as to strike a passenger train coming on the other track from the opposite direction, severely injuring plaintiff, who was riding as a passenger thereon. ${ }^{11}$ The affirmance of judgment on a large verdict in such a case is in line with the usual practice.

In Dieffenbach $v$. New York, etc. R. R., ${ }^{12}$ the facts as to the collision producing plaintiff's injury are meager. Plaintiff, a passenger in a sleeping car, was severely injured, when a train of defendant crashed into the car, demolishing it. This is probably a case of reckless misconduct, as such collisions are usually produced only by lack of or disregard of signals.

In Louisville, etc. R. R. v. Mitchell, ${ }^{13}$ because he was given erroneous information as to train schedule, plaintiff, a conductor, had his work train on the main track, where it was struck by another of defendant's trains, injuring plaintiff. May not the giving of erroneous information to a conductor as to the movement of trains on his line be said to be reckless misconduct? Before giving information to the conductor, the despatcher should

${ }^{10} 323$ Mo. 662, 2I S. W. (2d) 873 (I929), certiorari denied, 280 U. S. 6I4, 50 Sup. Ct. I62 (1929).

ni Walker v. Erie Ry., 63 Barb. 260 (N. Y. I872).

225 App. Div. 9I, 38 N. Y. Supp. 788 (I896).

${ }_{13}{ }_{173} \mathrm{Ky}$. 622, I9I S. W. 465 (I9I7). Does not the giving of such information in reckless disregard of its truth or falsity compare with the recklessness of accountants, of which Cardozo, C. J., speaks in Ultramares Corporation v. Touche, $255 \mathrm{~N}$. Y. I70, I7-4 N. E. 44I (I93I)? Is it not even more serious, as it affects the safety of human lives, and not merely the conservation of financial interests? 
have examined his schedule and ascertained that the information given was correct. It would seem that the giving of such information without carefully checking, where human lives are at stake, may well be regarded as more than mere negligence.

A somewhat similar case is International, etc. R. R. v. Vanlandingham, ${ }^{14}$ wherein plaintiff, defendant's locomotive engineer, a stranger to the road, was not supplied with a time-card. Consequently he ran his train into cars standing on the main track, and was badly injured. Defendant was found negligent in having freight cars on its main line and in not protecting with a flagman the train on which plaintiff was engineer. This is seemingly a case of reckless misconduct.

In Chesapeake \& Ohio Ry. v. Dixon, ${ }^{15}$ plaintiff, a thirty-seven-year-old railroad section man, suffered loss of a leg below the knee, injuries to the coccyx and pelvis, and complete loss of earning power. He continued to require constant personal attention. A verdict for $\$ 20,000$ was held not excessive. Defendant's employees, in producing the collision in which plaintiff was injured, committed what was rather clearly reckless misconduct, in proceeding without flag protection under conditions making such protection imperative.

In Wilson v. Baltimore \& Ohio R. R., ${ }^{16}$ plaintiff, a conductor, was badly injured, and was rendered a helpless cripple, the cause of his injury being the construction of tracks too close together. A verdict for $\$ 45$,000 was upheld. May it not be said that the construction of tracks so close together as very obviously to make the work of railroad trainmen on such tracks unsafe is reckless misconduct? It seems to be the wilful taking of a chance of causing death or serious personal injuries.

In St. Louis, etc. Ry. v. Coke, ${ }^{17}$ plaintiff, a conductor, was severely injured by the collapse of a defective bridge under his train. There was some evidence from which it could be inferred that the defendant was guilty of reckless misconduct as to the manner of building or maintenance. A verdict for $\$ 25,000$ was upheld.

Recklessly going ahead and striking a person plainly visible and at a considerable distance when first seen seems to be a quality of conduct that naturally incurs the resentment of courts as well as of juries. An instance of a large verdict for injuries so caused is Nagi $v$. Detroit United Ry., ${ }^{18}$

14 38 Tex. Civ. App. 206, 85 S. W. 847 (1905).

$15218 \mathrm{Ky}_{.} 84,290 \mathrm{~S}$. W. 1064 (I927). See facts in first report of same case, $212 \mathrm{Ky}$. 738, 280 S. W. 93 (I926).

${ }_{10}$ I94 Ill. App. 49I (Igr5). In Westover v. Wabash Ry., 6 S. W. (2d) 843 (Mo. 1928), certiorari denied, 278 U. S. 632,49 Sup. Ct. 31 (I928), plaintiff, a 35 -year-old switchman, lost his right hand and lower fourth of right forearm and toes and tips of metatarsal bones of left foot, by being knocked from an engine step to a point beneath the engine by a switch stand located too near the track. The verdict was reduced from $\$ 30,000$ to $\$ 22,500$. It seems a case of reckless misconduct.

${ }_{17}$ II8 Ark. 49, 175 S. W. II77 (r9I5).

${ }^{13} 23 \mathrm{I}$ Mich. 452,204 N. W. I26 (I925). 
in which plaintiff, in a stalled automobile, was struck by defendant's electric car, although the motorman could have seen plaintiff's automobile two and one-half or three blocks away. Plaintiff's hands were injured, both arms were broken, his left leg was crushed, with stiffening of the knee, part of his nose was lost, his upper jaw-bone was broken, his power of chewing was impaired, he had to walk on crutches for sixteen months, and with a cane for five months. He was kept from work for nearly two and one-half years. $\mathrm{He}$ was thirty-three years old, earning $\$ 6$ per day plus a bonus of $\$$ Io a month if he worked thirty days. Plaintiff's money loss up to the time of the trial was $\$ 6400$. Judgment was reduced from $\$ 30,000$ to $\$ 21,000$. It was a very clear case of reckless misconduct.

Very similar in quality of conduct is any case in which defendant's electric car is run across a street intersection at high speed without keeping a lookout. Such a case is Bennett $v$. Central Califormia Traction Co. ${ }^{19}$ in which plaintiff, an eighteen-year-old girl, received the following injuries, when the automobile in which she was riding was struck by defendant's street car: lower jaw-bone broken in three places, chin-bone splintered, two teeth driven into upper jaw-bone, inability for a long time to chew food, defect in vision preventing the use of the eyes for reading or work, and such injury to the face as to render it hardly recognizable. A verdict for $\$ 25,000$ was held not excessive. The facts seems to indicate reckless misconduct.

In Griswold v. Chicago Railways Co. ${ }^{20}$ plaintiff, a woman fifty years old, was so badly injured as to be confined to the hospital for over seven months, during six months of which time her legs and body were in steel and wooden casts and splints, and thereafter she had to walk on crutches and continued to suffer pain. Her injuries resulted in high blood pressure, apoplexy, and paralysis of one side of the body, from which she partly recovered. It was held that a verdict for $\$ 25,000$ was not excessive. The case seems to be on the border-line between negligence and reckless misconduct. Defendant's conductor caused the street car to start when plaintiff and other passengers had just alighted and had not had time or opportunity to pass out of the reach of the overhanging rear of the car, which, as the conductor must have understood it would do, struck the plaintiff, as the car

${ }^{29}$ I P. (2d) 47 (Cal. App. I93I). In Hart v. Farris, I3 P. (2d) 790 (Cal. App. 1932), one of defendants was driving an automobile at night, when he struck and injured plaintiff, a woman, who was riding a bicycle. Defendant could have seen plaintiff at a distance of 300 feet, by his headlights, if he had been keeping a careful lookout. There was some evidence that defendant was exceeding the legal speed limit. Plaintiff, who was $4 \mathbf{I}$ years old, suffered fractures of 4 ribs and $I$ vertebra, and also lacerations of the scalp, contusions of the liver, and heart trouble. Her activities would be greatly limited. Judgment on a verdict for $\$ 20,000$ was affirmed. High speed and failure to keep a lookout would seem to be sufficient to constitute reckless misconduct.

${ }^{20} 253$ Ill. App. 498 (I929). 
began to turn the corner. It seems fair to treat this case as one of reckless misconduct.

The reckless driving of motor cars on highways has sometimes given rise to large verdicts, finally sustained on appeal. In White v. Kretz Bros., ${ }^{21}$ defendant's truck was being driven in the middle of the paved road, up a hill, leaving only about three feet of the left side of the road vacant. Plaintiffs, husband and wife, were driving from the other direction, remaining on the right side of the road, and going at the rate of about thirty-five miles per hour. Plaintiffs, without fault, collided with defendant's truck. The husband's breastbone was fractured, and the wife suffered a fracture of the jaw, causing permanent injury. Both plaintiffs were forty-eight years old. A verdict for $\$ 20,060$ was held not excessive. It may well be said that defendants were guilty of reckless misconduct in occupying a portion of the left side of the road while approaching the top of the hill. The facts stated in the report do not indicate that either plaintiff was injured in such a way as to produce permanent incapacity to follow their usual pursuits, although their injuries were somewhat severe and painful. Perhaps the fact that such an unusually large verdict was sustained, for such injuries, indicates that the court was influenced by the very reprehensible nature of defendant's conduct. ${ }^{22}$

An able seaman sustained injuries, including permanent maiming of one arm and shortening and stiffening of one leg, probable impairment of the use of a knee, pain and suffering, and loss of earnings. He was awarded $\$ 28,54 \mathrm{I}$. This case seems one of the clearest cases of reckless misconduct. Plaintiff was ordered by defendant into the rigging of an unseaworthy ship, and, while plaintiff was there, dynamite was discharged into the masts of the ship, breaking and toppling the masts, striking the yardarm and rigging where plaintiff was, and causing plaintiff to fall to the deck below. ${ }^{23}$

${ }^{21}$ Io P. (2d) Ig8 (Cal. App. 1932).

$\because$ A case containing circumstances combining to make as serious an instance of reckless misconduct as is found among those involving motor cars on highways is Lincoln $\mathrm{v}$. Stone, 42 S. W. (2d) I28 (Tex. Civ. App. I93x), in which plaintiff, a 26 -year-old trained nurse, suffered permanent disabilities, disfigurement, fractured clavicle and jaw, pain and suffering, and impairment of ability to work at her occupation. Judgment on a verdict for $\$ 20,000$ was affirmed. The collision causing these injuries was between an automobile, in which plaintiff was riding as a guest, and a truck of defendant, which was being driven on the road at night, without a tail-light, without a red flag to the rear, without a driver's cab, and with timbers projecting at the sides and rear. Together, the facts indicate a low degree of visibility and a great capacity for harm. It seems that it can fairly be said that the combined facts of the case indicate reckless misconduct.

In Hughes v. Mississippi River \& B. T. Ry., 309 Mo. 560, 274 S. W. 703 (1925), plaintiff was injured in a collision produced by the failure of the driver of one of defendant's motor cars to give warning of approach at a dangerous curve, where the rules of defendant demanded that such warning be given. Plaintiff, a section hand, with a life expectancy of $3^{1} / 2$ years, was rendered a complete and permanent physical wreck, with pain and suffering continuing two years after the accident. A verdict for $\$ 21,168$ was held not excessive. The case seems to be one of reckless misconduct.

${ }^{3}$ In re Famous Players Lasky Corporation, 30 F. (2d) 402 (S. D. Cal. 1929). In Becker S. S. Co. v. Snyder, 3I Ohio App. 379, I66 N. E. 645 (1929), because of the gross 
Those familiar with the operation of coal mines know that the geological formation and the removal of large areas of coal often bring about a condition in which every intelligent person concerned in the working of the mine understands the very great danger of a cave-in of the roof of the mine, with a consequent crushing of miners, if the roof is not well supported by caps and props. In Starck $v$. Washington Union Coal Co., ${ }^{24}$ plaintiff, an employee in defendant's mine, was injured by a cave-in of the roof, through lack of props. Defendant had complained of the dangerous roof; but the foreman, on inspection, declared it safe, and yet promised to furnish props. A verdict for $\$ 20,000$ was upheld. A considerable chance of injury to plaintiff must have been consciously taken by defendant's foreman. This too may properly be termed a case of reckless misconduct.

In Bourke v. Butte Electric \& Power Co., ${ }^{25}$ damage to plaintiff's person resulted from failure of defendant to keep its electric wires insulated at a point where they ran over a tramway trestle to a mine where plaintiff worked. "Criminal disregard of the rights and safety of all persons" was alleged, and it would seem that the case may properly be treated as one of reckless misconduct. We have no statement in the opinion as to whether the large verdict allowed to stand was entirely compensatory damages, as exemplary damages were also claimed.

Another instance of a large verdict, which was upheld on appeal, is Boreman-Hicks Lumber Co. v. Robinson, ${ }^{26}$ wherein plaintiff, a decker in a logging camp, was injured when an unusually large log became disengaged from its decker hook and rolled against a tree, which fell against plaintiff, fracturing his skull and causing other serious injuries. The report of the case gives no statement indicating the final results of plaintiff's injuries or the value of his earning power. A verdict for $\$ 30,000$ was upheld. The defendant apparently had violated its duty to plaintiff in a number of ways and had consciously taken the chance of causing just such an injury. It seems to be a case of reckless misconduct.

In Decatur Cotton Seed Oil Co. v. Belew, ${ }^{2 \pi}$ a very large verdict was allowed to stand, where defendant's building collapsed upon plaintiff and injured him very seriously. There is much reason to say that this was a case of reckless misconduct.

Recklessness in the handling of gasoline near fire caused the serious injuries complained of in Waters-Pierce Oil Co. $v$. Snell, , $^{28}$ and a verdict

negligence or reckless misconduct of the defendant in failing to wash down the deck of its ship, dirty and slippery from water and oil, plaintiff, a seaman, about is years of age, fell into a hatch and down into the hold, breaking his back, arm, and leg, being permanently crippled. A verdict for $\$ 20,000$ was held not excessive.

${ }^{2 s} 6 \mathrm{I}$ Wash. 213, II2 Pac. 235 (I9ro).

${ }^{25} 33$ Mont. 267, 83 Pac. 470 (1905).

${ }_{20}$ I6 F. (2d) 240 (C. C. A. 9th, I926).

${ }^{z}$ I78 S. W. 607 (Tex. Civ. App. Igr5).

${ }^{2} 47$ Tex. Civ. App. 413, 106 S. W. I70 (1907). 
for $\$ 30,000$ was upheld. In Thirkell v. Equitable Gas Co., ${ }^{29}$ plaintiff, as the result of an explosion of defendant's gas main, suffered injuries of the spine and chest, loss of voice, the death of his wife, and the loss of \$2000 in personal property. A verdict for $\$ 50,845.50$ was held excesive by only $\$ 17,4.70 .50$. Plaintiff was a labor foreman, aged forty-six, and earning $\$ 170$ a month. The facts as to this explosion, as reported in King v. Equitable Gas Co., ${ }^{30}$ indicate gross neglect amounting to reckless misconduct, defendant's own evidence showing that it had not sufficiently cared for the gas main for years previous to the time of the catastrophe.

A case in which the verdict, even as finally reduced, was very large, is Vaughan v. St. Louis Merchants' Bridge Terminal Ry., in which an assistant yardmaster, earning $\$ 225$ a month, suffered amputation of his right arm between elbow and shoulder, a skull fracture, impairing his hearing for some time, and causing large expenditures for medical treatment; but he was not permanently disabled physically from earning a livelihood. His age was forty-one, and his life expectancy was 26.76 years. A verdict for $\$ 50,000$ was reduced to $\$ 25,000$. This is seemingly a case of reckless misconduct, as there was apparently a conscious violation, by defendant, of an important and well known rule, and the violation submitted plaintiff to a very great hazard, of which defendant must have consciously taken the chance.

An unusually large verdict was upheld in Lamar $v$. Collins, ${ }^{32}$ in which plaintiff, a household maid, sustained fractures of a cheek-bone, jaw-bone, and arm. The arm injury caused several operations and was permanent. She underwent extreme pain over a long period, and expenses were heavy. Judgment on a verdict for $\$ 35,000$ was affirmed. The court's finding indicates reckless misconduct.

In Whittington v. Westport Hotel Operating Co., ${ }^{33}$ plaintiff, a twentythree-year-old carpenter, suffered permanent injury, causing inverted foot and injury to sacroiliac joint, concussion of the brain and spine, and suffering. A verdict for $\$ 20,000$ was held not excessive. Reckless misconduct seems to have caused the injury.

The twenty-eight decisions just recounted, all allowing verdicts to stand at $\$ 20,000$ or more, seem, in every instance, to be founded upon acts amounting to reckless misconduct. Of these decisions, several allow very large damages, where the facts stated indicate only moderate damage.

\footnotetext{
${ }^{20} 307$ Pa. 377, 16r Atl. 313 (1932).

${ }^{\infty} 307 \mathrm{~Pa} .287$, I6I At1. 65 (I932).

${ }^{31} 322$ Mo. I39, I8 S. W. (2d) 62 (1929).

$\approx 252$ Ill. App. 238 (I929).
}

${ }^{33} 326$ Mo. III7, 33 S. W. (2d) 963 (I930). See also McAuliffe v. New York, etc. R. R., I72 App. Div. $597, x 58$ N. Y. Supp. 922 (I916), in which, in a case of obvious reckless misconduct, the verdict was reduced from $\$ 40,000$ to $\$ 25,000$. 
We shall now examine some cases in which judgments for $\$ 20,000$ or more were permitted to stand, in instances wherein probably no more than mere negligence appears.

In Smith v. Acme Boiler \& Tank Co. ${ }^{34}$ plaintiff, a thirty-six-year-old boiler-maker, earning $\$ 37.40$ weekly, was rendered a helpless cripple. A verdict for $\$ 20,000$ was held not excessive. The facts seem to indicate mere negligence.

Plaintiff, an unmarried woman, twenty-four years old, in Hepner $v$. Libby, McNeill \& Libby, ${ }^{35}$ complained of leg burns, head injuries, brain concussion, fractured rib, hernia, neurosis, and other injuries received in a collision brought about by defendant's negligence. A verdict for $\$ 27,500$, reduced by the trial court from $\$ 40,000$, was sustained. The facts seem to have shown no more than. negligence.

In Haaga v. Saginaw Logging Co. ${ }^{36}$ plaintiff was struck and injured while crossing the railroad track of defendant at a grade crossing in an automobile as a guest of the driver. The conduct of defendant's servant was apparently no more than negligent. Plaintiff, twenty-one years old, was earning \$I 30 a month. The injuries caused practically a total loss of earning capacity, permanent suffering, and inconvenience in manner of living. A verdict for $\$ 40,000$ was held not excessive. Plaintiff's injuries were unusually severe, he was young, and his injuries would presumably affect him for many years. It is one of those cases in which the damage is so great that, of whatever type the blameworthy conduct may have been, it is very hard to say that $\$ 40,000$ should be held excessive. Yet probably there are courts that would have been inclined to reduce so large a verdict for merely negligent conduct.

In Share v. Boston, etc. Railroad Corp., ${ }^{37}$ a verdict for $\$ 22,500$ was upheld, where the facts indicated only negligence, but the personal injuries proved were very severe.

Plaintiff in Galveston, etc. Ry. v. Cherry, ${ }^{38}$ a locomotive engineer on defendant's train, fell and was very seriously injured, by reason of a loose, defective, and insecurely fastened engine step. A verdict for $\$ 20,000$ was upheld. The case was treated by the court as one of negligence, and it is such a case, unless one could call the operation of a locomotive without inspection of its step reckless misconduct. On the whole, it seems only a case of negligence.

In Murphy v. Pacific T. \& T. Co., ${ }^{39}$ plaintiff was badly injured by the fall of a telephone pole on which he was working and an adjoining pole, the

${ }^{34} 326$ Mo. 734, 32 S. W. (2d) 576 (1930).

300 Pac. 830 (Cal. App. I931).

36 I65 Wash. 367, 5 P. (2d) 505 (I93I).

38 Gray 45 (Mass. I857).

${ }^{2} 44$ Tex. Civ. App. 344,98 S. W. 898 (1907).

$\approx 68$ Wash. 643, I24 Pac. II4 (IgI2). 
poles not being rendered safe and stable with guys. The foreman had guyed all poles that he considered dangerous. This seems to be a case of mere negligence. A verdict for $\$ 20,000$ was upheld.

In Brackett $v$. James Black Masonry \& Contracting Co., ${ }^{40}$ defendant negligently constructed a scaffold, on which another employee of defendant worked above plaintiff, and from which he fell upon plaintiff, breaking plaintiff's neck, with injury to the brain and spinal cord and complete incapacity to work thereafter. Plaintiff was thirty-three years old and was earning about $\$ 1000$ a year. A verdict for $\$ 22,500$, reduced from $\$ 30,000$, was held not excessive. Probably negligence only is involved.

Rose v. Missouri District Telegraph Co. ${ }^{41}$ was a case in which plaintiff, while working on a telegraph pole, fell forty-two feet to a pavement, as a result of the defective condition of a cross-arm. He was thirty-one years old, and was rendered a helpless invalid, unable to work, and condemned to a life of suffering and misery. He lost the sight of one eye completely, and the vision of the other eye was greatly impaired. His right leg was rendered useless, and, in order to go around at all, he was forced to use a brace and crutches. He suffered a serious fracture of the skull. His septum was so pushed over as to interfere with his breathing. His hearing was reduced to about one-fourth of normal. His shoulder was badly injured. The left side of his body was rendered numb, with partial paralysis. His memory was impaired, he was rendered nervous, and would be likely to continue to suffer. The verdict for $\$ 50,000$ was held excessive by $\$ 10,000$. The conduct of the defendant was probably only negligent, but the injuries were unusually severe.

Plaintiff, in Woods v. St. Louis Merchants' Bridge Terminal Ry., ${ }^{42}$ was a twenty-seven-year-old switchman earning $\$ 200$ per month. He suffered injuries resulting in permanent stiffening of the right arm, and amputation of a leg five inches below the knee. He was incapacitated for eight months, and could rarely put in a full day of work thereafter. A verdict for $\$ 30,000$ was held not excessive. The injuries resulted from the breaking of a brake-wheel. This seems a case of negligence only.

In Bond v. St. Louis-San Francisco Ry., ${ }^{43}$ plaintiff, a railway postal clerk, earning $\$ 2300$ per year, suffered fractured bones of shoulder, left hip, and right ankle, resulting in permanent disability, and also injuries to ear and eye. Judgment on a verdict for $\$ 85,000$ was affirmed, on condition of remittitur of $\$ 50,000$. The case seems one of mere negligence.

In the ten cases just examined, in which verdicts for $\$ 20,000$ or more were upheld in what seem to be cases of mere negligence, in every instance,

\footnotetext{
${ }^{40} 326$ Mo. 387,32 S. W. (2d) 288 (1930).

"128 Mo. Ioog, 43 S. W. (2d) 562 (I93I).

$\therefore 8$ S. W. (2d) 922 (Mo. 1928).

43288 S. W. 777 (Mo. I926).
} 
the injuries were unusually severe, destroying or almost destroying the earning capacity of the plaintiff, and, in several instances, rendering him a helpless cripple.

We shall next examine some cases in which verdicts for $\$ 20,000$ or more have been upheld, where the reported facts leave in serious doubt the question whether defendant's conduct amounted to reckless misconduct or to mere negligence.

In Skinner v. Davis, ${ }^{44}$ plaintiff, a young man of twenty-one, was so injured that one leg was shortened and atrophied, his nervous system shocked and deranged, and he was incapacitated to perform manual labor. A verdict for $\$ 20,000$ was held not excessive. Whether there was reckless misconduct in producing the collision in which plaintiff was injured, we cannot ascertain from the facts reported.

In Adskim v. Oregon-Washington R. \& N. Co. ${ }^{45}$ plaintiff, a brakeman, suing under the federal employers' liability act, was injured when, in the darkness, he alighted on a pile of cinders and gravel placed between the tracks by defendant's employees. The facts in the case seem to indicate that defendant's employees knew that to leave such a pile between tracks presented a serious hazard of exactly the kind of injury that did occur; but, from the facts stated in the reports, we cannot learn with satisfactory certainty whether this was so. Plaintiff was thirty-eight years old, with life expectancy of 29.62 years, and earned $\$ 250$ a month. He suffered serious and permanent injury to the spine. A verdict for $\$ 23,256.50$ was held not excessive.

In re Central Railroad of New Jersey ${ }^{46}$ was a case in which a verdict for $\$ 30,000$ for personal injuries to a forty-nine-year-old woman, with an expectancy of life of over twenty years, for personal injuries and consequent loss of business amounting to $\$ 3500$ per year, was held not excessive, the court saying that, if anything, the sum was too low. The case says nothing about the facts constituting the defendant's fault in the collision causing the injuries.

H. L. Hunt, Inc. v. Frisby ${ }^{47}$ was a case in which defendant caused serious and permanently incapacitating injuries by negligently engaging a clutch. The facts stated are meager, but the case is probably one of negligence only. Damages were reduced from $\$ 25,000$ to $\$ 20,000$. Plaintiff was caused apparently permanent pain.

The plaintiff, a brakeman, in Missouri Pacific R. R. v. Remel, ${ }^{48}$ in the performance of his duties, was riding on the last car, to protect the

\footnotetext{
${ }^{44}$ 312 Mo. 58I, 280 S. W. 37 (1926).

45 I34 Ore. 574, 294 Pac. 605 (1930).

${ }_{52} \mathrm{~F}$. (2d) 20 (C. C. A. 2d, I93I).

${ }_{51}^{4}$ S. W. (2d) 516 (Ark. I932).

${ }_{4}{ }_{48} \mathrm{~S}$. W. (2d) 548 (Ark. I932).
} 
train as it backed into a switch. Seeking damages under the federal cmployers' liability act, he alleged that because of the negligence of the engineer in stopping the train in an unusual and violent manner, plaintiff was thrown from the car to the ground and so injured that he would never again be able to do manual labor. The verdict for $\$ 60,000$ was reduced to $\$ 40,000$. Plaintiff was thirty-nine years old, earning $\$ 250$ a month. $\mathrm{He}$ sustained serious injuries to the spine, the first lumbar vertebra being crushed and the spinal cord pinched. He would probably suffer pain for the rest of his life and would gradually grow worse. This seems to be a case of mere negligence, and even the fact of negligence was seriously disputed by the defendant; but there is some reason to classify this case as in the doubtful zone between negligence and recklessness, inasmuch as the likelihood of such injuries from a violent stopping of a train is great, and it may be plausibly argued that the engineer, in so stopping, is consciously taking a serious chance of causing severe injuries to persons on board the train.

Masonite Corporation v. Lochridge ${ }^{49}$ was a case in which plaintiff, an employee of defendant, was injured by a shock received from an electric machine, which had not been inspected by defendant before being turned over to plaintiff for operation. For safety the machine should have been inspected and grounded. Plaintiff's earning capacity was practically destroyed. He was forty-one years old, and had been earning $\$ 7.50$ per day. It was held that a verdict for $\$ 20,000$ was not excessive. From the few facts given, it is impossible to say whether the omission of inspection and grounding occurred under such circumstances as to make it amount to reckless misconduct.

In Hommell v. Errington, ${ }^{50}$ plaintiff, a lawyer, was injured by the combined negligence of a driver in whose automobile he was a guest and of the driver of a truck, with which a collision occurred. From the report of the case, it is doubtful whether the defendant trucking company was guilty of more than negligence, although there was some evidence that their truck entered the road from another road at thirty-five miles an hour. Plaintiff's injuries included injuries to the brain, fracture of pelvic bones and of the two bones below the pubis, severe injury to urinary system, loss of some teeth, partial impairment of memory and of hearing. He was confined to a hospital bed, in a strait-jacket, for five weeks, and thereafter for some months was confined to a bed in his father's home. His recovery remained uncertain. No information is given, by the report, as to plaintiff's age or earning capacity. A verdict for $\$ 25,000$ was sustained.

Plaintiff, a married woman, thirty-nine years old, was run down in the street by an automobile belonging to defendant. The report indicates noth-

${ }^{4}$ I40 So. 223 (Miss. I932).

${ }^{20}$ Io N. J. Misc. 93, 157 Atl. 673 (I932). 
ing as to the nature of defendant's conduct. Plaintiff was rendered a physical wreck for life. A verdict for $\$ 26,000$ was sustained in Sanford $\%$. Totty Co. ${ }^{51}$

In Sellers v. Wood Hydraulic Hoist \& Body Co., ${ }^{52}$ plaintiff, a woman fifty years old, who had been conducting a profitable business before her injury, suffered the following elements of damage: fractured skull rendering her unconscious and irrational for weeks, the necessity of a guardian and constant attendant even at the time of the trial, seven months after the injury, probably permanent inability to resume any employment requiring concentration, broken bones in right hand, teeth in lower jaw so loosened as to require extraction, and $\$ 2500$ for medical attention. A verdict for $\$ 20,000$ was held not excessive. From the few facts stated, it is impossible to say whether the defendant was guilty of reckless misconduct.

In the nine cases just examined, more or less doubtful cases on the point of negligence or of reckless misconduct, in every instance the damages were very great, and probably in every case there was a permanent incapacity to do work as the plaintiff had done work before the injuries. This incapacity seems to have been total or nearly so in every case.

We shall now examine cases in which the defendant has seemed guilty of no more than negligence, where verdicts have been reduced from $\$ 20,000$ or more to figures under $\$ 20,000$ or have been set aside as being excessive.

In Mitchell v. Tacoma Ry. \& Motor Co., ${ }^{53}$ a verdict of \$30,000 for the negligent striking of plaintiff by defendant's street car was reduced to $\$ 12,000$.

In Renne v. United States Leather Co., ${ }^{54}$ plaintiff, a sixteen-year-old boy, sued for personal injuries sustained while in the employ of defendant and riding on top of a freight car for the purpose of setting the brake thereon. While the car was being backed into the yards, plaintiff was swept off the top by an exhaust pipe extending horizontally from defendant's boiler house, over its side tracks. If the car had not happened to be much higher than the other cars in common use at the place, the accident probably would not have occurred. In placing the exhaust pipe, the defendants do not seem to

${ }^{51}$ 158 At1. 99 (N. J. 1932).

205 Cal. 519, 27 I Pac. I055 (1928). See Missouri, etc. Ry. v. Smith, I72 S. W. 750 (Tex. Civ. App. 19I5), in which the verdict was reduced from $\$ 50,000$ to $\$ 30,000$. Although the verdict was very large, even as reduced, it seems to be grounded entirely in the great amount of damage actually done, for the case appears to be one of negligence.

See also St. Louis S. W. Ry. v. Kendall, II4 Ark. 224, I69 S. W. 822 (I914), in which the circumstances seem to point to mere negligence. The judgment was reduced from $\$ 38,000$ to $\$ 20,000$.

A somewhat similar case is Strand v. Great Northern Ry., IOI Minn. 85, III N. W. 958, II2 N. W. 987 (I907), in which plaintiff, a fireman, was badly injured by the explosion of a locomotive boiler. There was some evidence of contributory negligence of plaintiff. Evidence on the question of defendant's negligence was conflicting. It seems that there is no indication of reckless misconduct. A verdict of $\$ 30,000$ was reduced to $\$ 20,000$.

53 I3 Wash. 560, 43 Pac. 528 (I896).

of 107 Wis. 305,83 N. W. 473 (1900). 
have been consciously taking a chance of doing harm to any one. The case seems to be one of mere negligence. The injuries to plaintiff were very severe. The plaintiff was put his choice of a remittitur of all damages in excess of $\$ 12,000$ or a reversal.

Amsdill v. Detroit Motorbus $C 0 .{ }^{55}$ is a case in which plaintiff, a passenger, was thrown down a stairway on a bus, by a sudden starting. She was a married woman, and made no claim for diminution of earning power. A verdict for $\$ 25,000$ was reduced to $\$ 15,000$. From the facts it is not entirely clear whether there was negligence or reckless misconduct; but, when one considers the plan of the modern double-deck bus and the ordinary method of its operation, it would seem likely that this is a case of mere negligence.

In Hoag v. Washington-Oregon Corporation, ${ }^{56}$ while plaintiff, a lineman, was engaged in tying a wire to an insulator, the electric current was turned into the wires without warning. Negligence was alleged, for turning on the current in this manner and also for the method of placing and insulating wires. The facts, as indicated in the report, do not clearly indicate whether there was reckless misconduct or mere negligence; but it seems to have been considered merely a case of negligence. The verdict was reduced from $\$ 30,000$ to $\$ 14,000$.

Koch v. Southern Cities Distributing Co. $^{57}$ was a case in which plaintiff was injured by a gas explosion caused by defendant's negligence. At the time of injury, he was thirty-eight years old and earning $\$ 250$ per month. Defendant seems to have taken no risk consciously. Plaintiff suffered lacerations, contusions, bruises, a broken nose and foot, and was rendered a nervous wreck. A verdict for $\$ 35,995$ was reduced to $\$$ I 5,995 .

In Sallee v. St. Louis-San Francisco $R y .{ }^{58}$ plaintiff was so injured that one leg was amputated below the knee, and there was some brain injury. $\mathrm{He}$ was a fifty-five-year-old switchman, earning $\$ 275$ to $\$ 300$ per month. It seemed to be a case of mere negligence in maintenance of hand brakes. The verdict was reduced from $\$ 30,000$ to $\$ 17,000$.

In the six negligence cases just examined, verdicts were reduced from amounts equal to or exceeding $\$ 20,000$ to amounts less than $\$ 20,000$. In some of these cases, in view of the very great harm done to the person of the plaintiff, the defendant might regard himself as fortunate in obtaining any reduction in the amount of the judgment at all. It certainly seems that in Koch v. Southern Cities Distributing Co., and Sallee v. St. Louis-San Francisco $R y$, the courts dealt mercifully with merely negligent defendants.

\footnotetext{
${ }^{\varpi} 233$ Mich. I50, 206 N. W. 494 (I925).

${ }^{50} 75$ Ore. 588, 144 Pac. 574, I47 Pac. 756 (I9I4).

or I8 La. App. 664, I38 So. I78 (I93I).

${ }^{\infty} 321$ Mo. 798 , I2 S. W. (2d) 476 (I928).
} 
On the other hand, where a verdict is reduced in a reckless misconduct case, the excessiveness, it seems, has to be much clearer than has been required in some of the negligence cases and probably somewhat clearer than has been required in any of them. Decisions granting a reversal for excessive damages or ordering a remittitur, in the reckless misconduct cases, are ordinarily cases in which it could be said, almost at a glance, that the damages were grossly excessive. A fair example of this kind is Yazoo, etc. Ry. v. Cobb, ${ }^{59}$ in which plaintiff was injured in a collision caused by the failure of defendant's telegraph operator to deliver properly a train order to the conductor of a train. The operator placed the message containing the order upon a table in front of the conductor when he called for orders, instead of deliverit to him and having him read it aloud as required by the rules of the company, and the conductor failed to take the orders with him when he left. The court said in another case based on the same facts, $\dot{Y} a z o o$, etc. Ry. $v$. Farr," "We have no doubt that the operator was gravely delinquent in the discharge of duty." When one studies the two cases carefully, it seems that the conduct of the operator and of the conductor may well be denominated reckless. But the verdict for $\$ 25,000$ was very clearly and grossly excessive. The court said, "We think the injury is not such as will cause permanent disability." The reduction of the judgment from $\$ 25,000$ to $\$ 12,500$ left the plaintiff a sum that is unusually large for damage not producing any permanent disability.

It seems easier to get large verdicts set aside in cases of personal injuries arising from negligence than in the cases of such injuries arising from reckless misconduct.

In cases of wilful injury to another's business, by means of unfair trade practices in violation of the common law ${ }^{61}$ or in violation of an anti-

${ }^{60} 94$ Miss. 56r, 48 So. 522 (I909). Louisville, etc. R. R. v. Long, 94 Ky. 4 Io, 22 S. W. 747 (1893), is a clear case of reckless misconduct. Plaintiff, a passenger, was severely injured by the collision of a freight train with the passenger car, the crew having left the passenger car on the main track without flagging the apprcaching train. But the $\$ 26,000$ verdict, which was set aside, was clearly excessive. Likewise, an apparently grossly excessive verdict for $\$ 25,000$ was reduced to $\$ 5,000$ in Peyton v. Texas \& P. Ry., 4I La. Ann. $86 \mathrm{I}, 6$ So. 690 ( 1889 ), which seems to be a reckless misconduct case.

In Alabama Power Co. v. Goodwin, 214 Ala. 15, I06 So. 239 (1925), plaintiff, a 53-year-old married woman, while a passenger in defendant's street car, was injured through what seems to have been "wanton negligence", or "reckless misconduct", on the part of defendant's motorman, though the facts stated in the report above cited and in 210 Ala. 657, 99 So. 158 (1924), and in the report of the case brought by the husband for the same injuries to his wife, this plaintiff, 2ro Ala. 388, 98 So. 124 (I923), are very meager. A verdict for $\$ 20,000$ was held excessive by $\$ 6,500$. But it is to be noticed that her expenses of treatment and illness had been paid for by defendant. It seemed improbable that she would continue to suffer for life to any considerable degree. When this fact is considered, the amount finally allowed seems liberal.

${ }^{\infty} 94$ Miss. 557, 559, 48 So. 520, 52I (I909).

a. Defendant, by defamation and other unfair trade practices, attempted to destroy the business of plaintiff, and actually did large damage. There was evidence of damage to the amount of $\$ 30,000$ per year. Damages were assessed in the sum of $\$ 100,000$. Judgment was affirmed. ILion Oil Co. v. Sinclair Refining Co., 252 Ill. App. 92 (I929). See also Morand Bros., Inc. v. Chippewa Springs Corp., 2 F. (2d) 237 (C. C. A. 7th, I924), certiorari denied, 267 U. S. 592, 45 Sup. Ct. 229 (I925). 
trust statute, ${ }^{62}$ or by means of infringement of patents, ${ }^{63}$ the courts will more readily allow large verdicts to stand than in cases where the defendant has innocently made use of the principle of plaintiff's patent or has otherwise innocently done a wrong to plaintiff's business. Undoubtedly one factor that makes for liberality in allowing damages in many of these cases is the uncertainty of damage caused by the acts of defendant. The very acts of the defendant, in some instances, have produced the uncertainty. Many of the cases are such that the plaintiff can present no evidence of certain damage, excepting a few instances of injury to his business and of a widespread indulgence by defendant in his wrongful practices.

Any study of the tendencies of courts in this field is beset with great difficulties. In many cases, it is impossible to weigh with any accuracy the elements of actual damage to the plaintiff, and, in a considerable number of the cases, it is difficult to learn much about the degree of fault of the defendant or even with any reasonable certainty to classify his conduct as negligent or as reckless; but, on the whole, this much stands out with a fair degree of clearness: a high degree of fault in the defendant makes more likely the affirmance of judgment on a very large verdict, even for compensatory damages alone, and will result in a less thorough scrutiny by the court of facts affecting the solution of the question of excessiveness of damages. On the other hand, a lower degree of fault in the defendant causes the court to examine more closely all of the facts bearing upon excessiveness of damages, and to be more willing to reverse for excessiveness.

¿ See Story Parchment Co. v. Paterson Parchment Paper Co., 282 U. S. 555, 5I Sup. Ct. 248 (I93I); Eastman Kodak Co. v. Southern Photo Materials Co., 273 U. S. 359, 47 Sup. Ct. 400 (Ig27).

(All doubts should be resolved in complainant's favor, for the infringement has been declared by this court to have been deliberate." Coffield Motor Washer Co. v. Wayne Mfg. Co., 255 Fed. 558 , at 560 (C. C. A. 8 th, I918). 